\title{
Untreated Childhood Visual Pathway Glioma
}

National Cancer Institute

\section{Source}

National Cancer Institute. Untreated Childhood Visual Pathway Glioma. NCI Thesaurus.

Code C115957.

A finding of visual pathway glioma in childhood that has not been treated. 